\title{
Effect of pre gelatinization and annealing on the chemical composition, functional and pasting properties of starch prepared from unripe banana fruits
}

\author{
Peter Isah Akubor*1 and Theresa Igba ${ }^{2}$ \\ ${ }^{1}$ Department of Food Science and Technology, Federal University Wukari, Taraba State, Nigeria. \\ ${ }^{2}$ Department of Food Science and Technology, University of Umkar, Umkar, Benue State, Nigeria. \\ *Email: akuborpeter@gmail.com
}

\begin{abstract}
The study was to assess the effect of pregelatinization and annealing on the functional and pasting properties of starch prepared from unripe banana fruit. Starch was prepared from unripe banana (Musa spp) fruits. The banana starch was modified by pregelatinization and annealing processes. The unmodified, pregelatinized and annealed starches were assessed for the proximate composition, functional and pasting properties. The crude protein, fat, crude fiber, ash, moisture and carbohydrate contents of the unmodified banana starch were 3.75, 1.62, 2.43, 4.75, 9.50 and $77.95 \%$, respectively. Both pre gelatinization and annealing processes decreased the crude fiber, crude fat, ash, crude protein and carbohydrate contents but increased the moisture content. The bulk density decreased from $0.97 \mathrm{~g} / \mathrm{ml}$ for the unmodified banana starch to $0.64 \mathrm{~g} / \mathrm{ml}$ for the pre gelatinized starch and $0.39 \mathrm{~g} / \mathrm{ml}$ for the annealed starch. The pre gelatinization and annealing processes decreased the foaming properties, water absorption capacity but increased the oil absorption capacity. Only the pre gelatinization process increased the emulsion capacity of the banana starch but the emulsion stability of the banana starch was improved by the two modification processes. The swelling index and solubility of the banana starch were decreased by pre-gelatinization and annealing processes. The peak viscosity, final viscosity, set back viscosity, break down viscosity, pasting time and pasting temperature of the unmodified banana starch were 159.57, 237.57, 71.47, 20.16, 5.84 and 85.8 RVU, respectively. The pregelatinization and annealing processes increased all the pasting properties of the banana starch evaluated except set back viscosity that was decreased by the pre-gelatinization process. It is concluded that the proximate composition, functional and pasting properties of banana starch varied with pre-gelatinization and annealed processes. The functional properties lend the unmodified and modified banana starches to various food applications.
\end{abstract}

Keywords: Banana, Starch, Pre-gelatinization, Annealing, Composition, Functional properties.

Paper Cited: Akubor, P.I. and Igba, T. (2019). Effect of pre gelatinization and annealing on the chemical composition, functional and pasting properties of starch prepared from unripe banana fruits. South Asian Journal of Food Technology and Environment, 5(1): 807-816.

\section{Introduction}

Banana (Musa spp) is an important crop in the tropical and subtropical regions of the world. The fruit is either consumed ripe due to its high sugar content or unripe in many indigenous dishes that require high starch content. Banana is also processed into various forms such as juice, puree and flour which can be stored for long period of time and utilized for other purposes. Banana wine and banana chips prepared by deep frying of slices of unripe banana fruits are also common (Anuonye et al., 2012). Banana is rich in minerals such as $\mathrm{P}, \mathrm{Na}, \mathrm{K}, \mathrm{Ca}, \mathrm{Mg}, \mathrm{Fe}, \mathrm{Cu}, \mathrm{Zn}$ and Mn (Anuonye et al., 2012; Aurorea et al., 2009).Unripe banana is a good source of indigestible carbohydrates which was reported to be composed of mainly resistant starch (RS) and 
dietary fiber (Ovando- Martinel, 2009 ). Banana flour has been reported to provide 61.3$76.5 \mathrm{~g} / 100 \mathrm{~g}$ starch with fiber content of 6.3-15.5 g/100 g (Ovando- Martinel, 2009). The greater part of green banana starch is the resistant starch type 2 (RS2) which vary from 52.7 to $54.2 \mathrm{~g} /$ 100g. Resistant starch (RS) has attracted interest because of its positive effects on human colon and the implications for health (Gallant et al., 1995). Banana fruits also contain antioxidant compounds including polyphenols, catcholamines and carotenoids (Mohapatra et al., 2010). Several studies have suggested that consumption of unripe bananas exerts beneficial effects on human health (Gallant et al., 1995). This is associated with the indigestible components and the array of phytochemicals in banana (Langkilde, 2002). Starch contributes to textural properties of many foods and is widely used in the food industry as thickener, stabilizer and gelling agent (Chinma et al., 2012). Food processors prefer starches with better characteristics than those provided by native starches (Chinma et al., 2012). Native starches have limited use in the food industry for they produce weak-bodied, cohesive, rubbery pastes when cooked and give undesirable gels when the pastes are cooled (Onimawo and Akubor, 2012). The gel also easily undergoes syneresis (Onimawo and Akubor, 2012). However, physical and chemical modifications expand the uses of starch (Zavreze and Diass (2011). Modification is done so that the resultant starch pastes can withstand the conditions of heat, shear and acid associated with processing conditions and to produce starch with specific functionalities (Ikegwu et al., 2011).

Starch modification is achieved by chemical derivatisation such as esterification, cross-linking, grafting, decomposition, acid hydrolysis and degradation. However, there is increasing awareness of the danger in the use of chemically modified starches in food components (Zavreze and Diass, 2011). This has led to increase awareness on physical modification of starch. Physical modification may involve pregelatinization and heat treatment of starch. Pregelatinization involves application of heat sufficient to bring about gelatinization of starch, followed by drying and grinding (Onimawo and Akubor, 2012). This generates starch with instantaneous cold-water solubility and thickening/gelling capabilities. Heat treatments include heat-moisture and annealing treatments, both of which cause physical modification of starch without gelatinization, damage to granular integrity or loss of birefringence (Zhang and Hubar, 2015). By definition, annealing involves heating of granular starch in water $(>40 \% \mathrm{w} / \mathrm{w})$ at a temperature above the glass transition temperature ( $\mathrm{Tg}$ ) but below that of the gelatinization onset temperature (Falade and Ayetigbo, 2015). Heat-moisture treated starches have improved consistency and viscosity stability in food with a $\mathrm{pH}$ of less than 4.5 whereas annealing-treated starches have enhanced viscosity profiles (Zavreze and Diass, 2011; Zhang and Hubar, 2015).

Improvement in property that can be obtained by starch modifications are reduction in the energy required to cook(improved gelatinization and pasting), modified cooking characteristics, increased solubility, either increased or decreased paste viscosity, increased freeze-thaw stability of pastes, enhancement of clarity, increased paste sheen, inhibition of gel formation, enhancement of gel formation and strength, reduction of gel syneresis, improvement of interaction with other substances, improvement in stabilizing properties, reduction in paste cohesiveness and improvement of stability to acid, heat and shear (Onimawo and Akubor, 2012; Zzhang and Hubar, 2015). For efficient use of banana starch as an ingredient for the food industry, it is important to determine the effect of modification on the functional properties of the starch (Falade and Ayetigbo, 2015). Functional properties are the characteristics of foods which dictate their behaviour, quality and acceptability during processing and storage (Falade and Ayetigbo, 2015). Flours are cooked into paste before eating. Therefore, the determination of the pasting characteristics of flours is essential in predicting quality index and the behaviour of paste during and after cooking (Bakare et al., 2012). Rapid visco analyser is used to determine the pasting properties of flours. Therefore, the objective of the study was to determine the effects of annealing and pregelatinization on the proximate composition, 
functional and pasting properties of starch prepared from unripe banana fruit.

\section{Materials and Methods}

Source of raw material: Unripe banana (Honduras variety) fruits were purchased from a local market in Gboko Township, Benue State, Nigeria. All chemicals used were of analytical grade.

Preparation of banana starch: Starch was extracted from the banana fruits using the procedure described by Aurorea et al., (2009). The fruits were peeled, cut into slices and then immersed in sodium metabisulphite solution $(0.5$ $\mathrm{g} / \mathrm{L})$ for $1 \mathrm{~h}$. The slices (1:5, slice: water) were macerated with distilled water at low speed (1200 $\mathrm{rpm}$ ) in a Waring blender for $20 \mathrm{~min}$. The resultant slurry was sieved through 100 mesh screen. The starch suspension was left overnight at refrigeration temperature $\left(6-8^{\circ} \mathrm{C}\right)$, washed several times with distilled water and centrifuged at 3,000 rpm for $15 \mathrm{~min}$. The sediment was dried at $40^{\circ} \mathrm{C}$ for $48 \mathrm{~h}$ in a convection oven (GP/100/CLAD/F/250/HYD, Leader, Mersey side), milled and stored at ambient temperature $\left(30 \pm 2^{\circ} \mathrm{C}\right)$ in sealed glass jars until required.

Preparation of pre-gelatinized banana starch: The pre-gelatinization of the native banana starch was carried out as described by Onimawo and Akubor (2012). The starch (300 g) was suspended in $1 \mathrm{~L}$ of distilled water and heated to $80^{\circ} \mathrm{C}$ for $15 \mathrm{~min}$ with slow mixing. The pregelatinized starch ( $1 \mathrm{~cm}$ thick) was spread on a stainless steel tray and dried in a convection oven at $40^{\circ} \mathrm{C}$ for $48 \mathrm{~h}$, milled and then stored at ambient temperature $\left(30 \pm 2^{\circ} \mathrm{C}\right)$ in sealed glass jars prior to use.

Preparation of annealed starch: The annealing of the banana starch was carried out according to the method of Ikegwu et al., (2011). The native starch $(10 \mathrm{~g})$ was mixed with $20 \mathrm{ml}$ of distilled water and the mixture was heated for $24 \mathrm{~h}$ in a sealed container in water bath at $50^{\circ} \mathrm{C}$. The mixture was then incubated for $24 \mathrm{~h}$ and the suspension was filtered through a Whatman No 1 filter paper and then hot air oven dried at $40^{\circ} \mathrm{C}$ for $72 \mathrm{~h}$. The dried samples were then sealed in polyethylene bags and stored at ambient temperature prior to use.
Chemical Evaluation: Moisture content was determined by hot air oven drying at $105^{\circ} \mathrm{C}$ to constant weight. Ash, protein ( $\mathrm{N}$ x 6.25), crude fiber and fat (solvent extraction) contents were determined by the AOAC (2010) methods. Carbohydrate was calculated by difference as $100-(\%$ Protein $+\%$ Fat $+\%$ Crude fibre $+\%$ Ash $+\%$ Moisture). The caloric value of the samples was calculated by multiplying the $\%$ protein, $\%$ fat and $\%$ carbohydrate contents by Atwater factors of 4, 9 and 4, respectively (AOAC, 2010). Tannins and trypsin inhibitors contents were determined as described by AOAC (2010).

Evaluation of functional properties: Water and oil absorption capacities were determined as described by Chinma et al., (2012). The foaming capacity and foam stability were determined by the methods of Chinma et al., (2012). Bulk density was determined as outlined by Onimawo and Akubor (2012). The method of Onimawo and Akubor (2012) was used to determine the least gelation concentration. Emulsion activity and emission stability were measured as described by Onimawo and Akubor (2012)

Evaluation of the pasting properties: Pasting viscosity was determined using the Rapid Visco Analyzer(RVA) as described by Chinma et al., (2012). The sample (3.5g) was put into $25 \mathrm{ml}$ distilled water in a dry canister and the dispersion was thoroughly mixed. The canister was then fitted into the RVA. The slurry was heated at the rate of $6^{\circ} \mathrm{C} / \mathrm{min}$ to $95^{\circ} \mathrm{C}$ and held at $95^{\circ} \mathrm{C}$ for 3 min. This was then cooled to $50^{\circ} \mathrm{C}$ at $6^{\circ} \mathrm{C} / \mathrm{min}$ and then held at $50^{\circ} \mathrm{C}$ for $5 \mathrm{~min}$. Total heating and cooling time was $20 \mathrm{~min}$. The experiments were conducted in 3 replications. The pasting properties from the pasting profile with the aid of thermocline for Windows Software connected to computer.

Statistical analysis: The data were analysed by analysis of variance using Statistical Package for Social Sciences(SPSS) version 17, 2007(SPSS, 2008). Means where significantly different were separated by the least significant difference (LSD) test. Significance was accepted at $\mathrm{p}<0.05$.

\section{Results and discussion}

Chemical composition of starches: The proximate composition of the unmodified and 
Peter Isah Akubor and Theresa Igba

modified banana starches is given in Table 1. The protein content of the unmodified starch (control) $(3.75 \%)$ was not significantly $(\mathrm{P}>0.05)$ different from those of the annealed starch (3.55\%) and the pre-gelatinized starch $(3.65 \%)$ Pre-gelatinization and annealing processes slightly decreased the protein content by leaching. The fat contents of the banana starches were not significantly different $(\mathrm{p}>0.05)$, values varied slightly from $1.55 \%$ in the annealed starch to $1.62 \%$ in the pre-gelatinized starch. The low fat contents of the starches would not encourage the development of rancidity during storage. The ash contents of the starches decreased slightly ( $>>0.05$ ) from $4.75 \%$ in the unmodified starch to $4.40 \%$ in the annealed starch and $4.53 \%$ for the pre gelatinized starch, probably due to dilution of the constituents by water used in the preparation of the starch and also by leaching. Ash content is a quality factor for flour as it represents the total mineral content which has been reported to be high in banana (Anuonye et al., 2012; Mohapatra et al., 2010). Banana has been reported to contain high amounts of potassium (400 mg/100g pulp) and magnesium (34 mg/100 g edible portion) (Aurorea et al., 2009). The moisture contents of the unmodified, pre-gelatinized and annealed starches were $9.50,9.83$ and $9.98 \%$, respectively. The increase in the moisture content was due to the incubation of the starch granules in excess water during the modification processes The increase in the moisture contents of the modified starches wasin agreement with the reports of the physically modified bambara groundnut starch (Ikegwu et al., 2011) and Mucunna pruriens bean starch (Ikegwu et al., 2011). Low moisture content of the starches is important for the shelf life stability of the products. High moisture enhances food spoilage by creating favorable condition for proliferation of microorganisms and deterioration of food by enzymes (Onimawo and Akubor, 2012). The moisture contents of the starches were within the $10 \%$ recommended for stability of foods (Yusuf et al., 2007). The carbohydrate content of the unmodified starch was slightly higher than those of the modified starches probably due to loss of soluble carbohydrate components through leaching.

Table 1: Proximate composition of unmodified and modified starches prepared from unripe banana fruit

\begin{tabular}{|l|c|c|c|}
\hline Composition (\%) & Unmodified starch & Pregelatinized Starch & Annealed starch \\
\hline Crude protein & $3.75^{\mathrm{a}} \pm 0.02$ & $3.65^{\mathrm{a}} \pm 0.01$ & $3.55^{\mathrm{a}} \pm 0.02$ \\
Crude fat & $1.62^{\mathrm{a}} \pm 0.03$ & $1.60^{\mathrm{a}} \pm 0.02$ & $1.55^{\mathrm{a}} \pm 0.01$ \\
Crude fiber & $2.43^{\mathrm{a}} \pm 0.01$ & $2.35 \mathrm{a} \pm 0.01$ & $2.30^{\mathrm{a}} \pm 0.03$ \\
Ash & $4.75^{\mathrm{a}} \pm 0.02$ & $4.53^{\mathrm{a}} \pm 0.03$ & $4.40^{\mathrm{a}} \pm 0.01$ \\
Moisture & $9.50^{\mathrm{a}} \pm 0.02$ & $9.83^{\mathrm{a}} \pm 0.01$ & $9.98^{\mathrm{a}} \pm 0.02$ \\
Carbohydrate & $77.95^{\mathrm{a}} \pm 0.03$ & $77.43^{\mathrm{a}} \pm 0.01$ & $77.39^{\mathrm{a}} \pm 0.01$ \\
\hline
\end{tabular}

Values are means \pm standard deviation of 3 replicates. Means within a row with the same superscript were not significantly different $(\mathrm{p}>0.05)$.

Functional properties of starches: The functional properties of the banana starches are presented in Table 2. The bulk densities of the native, pre-gelatinized and annealed banana starches were $0.97,0.39$ and $0.64 \mathrm{~g} / \mathrm{ml}$, respectively. The pre-gelatinization and annealing processes decreased the bulk density of the native banana starch. The bulk density of pre-gelatinized banana starch was the least $(0.39 \mathrm{~g} / \mathrm{m})$. This was probably caused by gelatinization which increased the porosity of the banana starch. Small bulk density value means that the material requires a large volume for a small amount of material or in other words the bulkier these materials. Only the pregelatinization process increased the emulsion capacity of banana starch. The emulsion capacity increased from $7.85 \%$ for the unmodified starch to $9.17 \%$ for the pregelatinized starch and decreased to $7.72 \%$ for the annealed starch. However, the modification processes significantly $(\mathrm{p}<0.05)$ increased the emulsion stability of banana starch where the annealing process had greater effect than the pre-gelatinization. The emulsion stabilities were $45.05,54.05$ and $60.43 \%$ for the unmodified; 
pre gelatinized and annealed starches, respectively.

The ability to absorb oil indicates the emulsifying potential of the flour (Onimawo and Akubor, 2012). The high emulsion stability of the modified starches is related to the oil absorption capacity of the modified starches which was higher than that of the unmodified starch (Table 2). The protein bodies in the pregelatinized banana starch (Table 1) may have contributed to the high emulsion capacity. The modification processes significantly $(p<0.05)$ decreased the swelling index of the banana starch. The swelling index decreased from 4.51 for the unmodified starch to 3.14 for the pre gelatinized starch and 3.20 for the annealed starch. Similarly, the modification processes decreased the solubility of the banana starch. Annealing was reported to reduce granular swelling in yam starch (Yusuf et al., 2007) and breadfruit starch (Bakare et al., 2012) which was attributed to the interplay of increased crystalline perfection and decreased hydration (Zevreze and Diass, 2011), amylase - amylose and/or amylopectin-amylopectin interaction, 1997), increased intra-granular binding forces and reinforcement of the granules (Adegunwa et al., 2012) and amylose-lipid complex formation (Adegunwa et al., 2012).
The water absorption capacity decreased from $84.12 \%$ in the unmodified starch to $72.4 \%$ for the pre-gelatinized starch and $77.45 \%$ for the annealed starch. The water absorption capacity of the modified starches differed significantly $(\mathrm{p}<0.05)$ with the pre-gelatinized starch having lower capacity to absorb water than the annealed starch. The decrease in the water absorption capacity of the modified starches suggests that the associative forces between the starch polymers in the granules were strengthened by the modification processes. This probably compacted the structure of the starch molecules. Loose starch structure has been reported to give high water absorption capacity (Yusuf et al., 2007). However, the modification processes increased the oil absorption capacity of the banana starch with annealing process exerting greater effect. The oil absorption capacities of the unmodified, pre-gelatinized and annealed starches were $84.15,88.52$ and $91.90 \%$, respectively. The modification processes probably decreased the hydrophilic groups of the starch molecules that would have allowed water retention but increased the density of the hydrophobic residues on the surface of the starch granules (Moorthy, 2002). The modified banana starches would be useful in food formulations where low water absorption capacity and high oil absorption capacity are required.

Table 2: Functional properties of unmodified and modified starches from unripe banana Fruit

\begin{tabular}{|l|c|c|c|}
\hline Functional properties & Unmodified Starch & Pre-gelatinized Starch & Annealed Starch \\
\hline Bulk density (g/ml) & $0.97^{\mathrm{a}} \pm 0.01$ & $0.64 \pm 0.03^{\mathrm{b}}$ & $0.39 \pm 0.01^{\mathrm{c}}$ \\
Water absorption & $84.12^{\mathrm{a}} \pm 0.14$ & $72.45^{\mathrm{c}} \pm 0.06$ & $77.49^{\mathrm{c}} \pm 0.01$ \\
Capacity (\%) & $7.83^{\mathrm{a}} \pm 0.14$ & & \\
Emulsion capacity (\%) & $4.51^{\mathrm{a}} \pm 0.01$ & $9.17^{\mathrm{a}} \pm 0.03$ & $7.72^{\mathrm{b}} \pm 0.03$ \\
Swelling index & $7.26^{\mathrm{a}}$ & $3.14^{\mathrm{a}} \pm 0.05$ & $3.20^{\mathrm{b}} \pm 0.03$ \\
Solubility index & $84.15^{\mathrm{c}} \pm 0.21$ & $6.25^{\mathrm{b}}$ & $6.36^{\mathrm{b}}$ \\
Oil absorption & $88.52^{\mathrm{b}} \pm 0.04$ & $91.90^{\mathrm{a}} \pm 0.14$ \\
Capacity (\%) & $45.05^{\mathrm{a}} \pm 0.07$ & $54.03^{\mathrm{b}} \pm 0.07$ & $60.43^{\mathrm{c}} \pm 0.02$ \\
Emulsion stability (\%) & $9.0^{\mathrm{a}} \pm 0.08$ & $5.0^{\mathrm{c}} \pm 0.04$ & $7.0^{\mathrm{b}} \pm 0.14$ \\
Foaming capacity (\%) & $85^{\mathrm{a}}$ & $55^{\mathrm{c}}$ & $75^{\mathrm{b}}$ \\
Foam stability (\%) & \multicolumn{2}{|c|}{$\%$} & \\
\hline
\end{tabular}

Values are means Standard deviation of three replicates. Means within a row with the same superscript were not significantly different $(\mathrm{p}>0.05)$.

The foaming capacity of the unmodified banana starch was $9.0 \%$ and decreased to $5.0 \%$ for the pre-gelatinized starch and $7.0 \%$ for the annealed starch. Foaming properties are used as indices of the whipping characteristics of flour. 
The foaming properties are important in the maintenance of texture and structure of different food products (such as ice cream and bakery products) during and after processing (Onimawo and Akubor, 2012).The modification processes may have caused inadequate electrostatic repulsions by the starch molecules which adversely affected the foaming capacity of the starch (Onimawo and Akubor, 2012). The modification processes may also have enhanced the loss of some proteins from the native starches (Onimawo and Akubor, 2012). The foamability of flour depends on the presence of flexible protein molecules which decrease the surface tension of water (Chinma et al., 2012).

The modification processes also decreased the foam stability of the banana starch. The native banana starch may have contained some proteins that are soluble in the continuous phase (water) which gave the starch some surface active properties (Adegunwa et al., 2012), hence the higher foam stability over the modified starches. The low foam stability of the modified starches may be linked to protein denaturation. The native proteins produced stable foams than the denatured proteins. Foam stability is important in food processing because the usefulness of whipping agents depends on the ability to maintain the whip for a long period of time (Ojinaka et al., 2009). Good foam stability suggests the presence of surface active proteins (Ikegwu et al., 2011).The unmodified banana starches would be suitable for use in food products that require high foaming capacity.

Pasting Properties of starches: The pasting properties of native banana starch and the modified banana starches are shown in Table 3 . The rapid visco analyzer measures the behavior of starch subjected to temperature and shearing forces. The peak viscosity of the unmodified banana starch (159.57 RVU) was significantly lower $(\mathrm{p}<0.05)$ than those of the pre-gelatinized (171.47 RVU) and annealed (178.53 RVU) starches. The final viscosities of the modified banana starches were significantly higher $(p<0.05)$ than those of the unmodified starch. The final viscosities of the unmodified, pregelatinized and annealed starches were 237.57,
238.70 and 245.14 RVU, respectively. The modification processes probably caused high damage of the banana starch. Peak viscosity was linked to the level of starch damage; in which high starch damage give high viscosity (Chinma et al., 2012). Peak viscosity is an important characteristic of starch granule in that it measures the capacity of starch to swell freely before physical break down (Bakare et al., 2012). Peak viscosity is the maximum viscosity developed during or after the heating stage. Maximum viscosity of starch suspension heated in excess water occurs after granule swelling has ceased and the increase in viscosity is due mainly to exudates released from the granules (Kapelko et al., 2013).

High peak viscosity was reported to correlate well with high swelling power which provides indication of the viscous load encountered during mixing of dough. The high peak viscosities of the modified banana starches were related to the swelling index of the starches shown Table 2 . The final viscosity is the viscosity at the end of the test. As gelatinized dispersion of starch is cooled, a loose paste or gel is formed depending on the starch concentration (Aina et al., 2009). At concentration above the critical concentration, a three dimensional network is established, where the swollen granules become embodied into continuous matrix of entangled amylose molecules (Moorthy, 2002). Such complex polymer matrix set as a viscoelastic gel in which the molecular association involving hydrogen bonding between chains is mainly physical rather than covalent cross links (Chin and Bertoft, 1998). The formation of such gel is indicated by increased viscosity and is known as the final viscosity in the pasting curve (Aina et al., 2009). Final viscosity is useful in determining the ability of flour/starch to form gel during processing (Yasumatsu et al., 1972). The banana starches would find applications in products requiring high gel strength and elasticity due to their high peak viscosity and final viscosity (Yusuf et al., 2007). High values of these parameters correlate well with high starch content (Yasumatsu et al., 1972). 
The modification processes significantly $(p<0.05)$ decreased the setback viscosity from 217.41 RVU for the unmodified banana starch to 215.94RVU for the pre-gelatinized starch but increased that of the annealed starch to 220.50 RVU. Set back viscosity is measured as the difference between the final viscosity and the trough viscosity. It is the phase of the pasting curve after cooling the starches to $50^{\circ} \mathrm{C}$. This stage involves re-association, retrogradation or re-ordering of starch molecules (Kapelko et al., 2013). Set back viscosity is a measure of the retrogradation tendency or syneresis of the starch, which implies the appearance of separate fluid droplets on starch gels. Low set back viscosity indicates greater resistance to retrogradation and products with low set back viscosity have low staling rate (Yasumatsu et al., 1972). Low set back viscosity is an indication of starch stability (Chinma et al., 2012). Thus, products containing pre-gelatinized banana starch would be more resistance to staling than the unmodified and the annealed starches. Thus, the annealed banana starch would not be useful for products in which syneresis or staling is a major quality problem (Ikegwu et al., 2011). Set back viscosity of flours is correlated with the texture of various food products (Falade and Ayetigbo, 2015).

The breakdown viscosity increased from 20.16RVU for the unmodified starch to 22.27 RVU for the pre gelatinized starch and 24.62 RVU for the annealed starch. The modification processes disorganized the starch structure and increased the breakdown viscosity of the banana starch. The annealing process increased the breakdown viscosity of the starch more than the pre-gelatinization process. The holding period is accompanied by breakdown in viscosity which is also known as shear thinning, hot paste viscosity, paste viscosity or trough viscosity (Falade and Aytigbo, 2015). Break down viscosity is the measure of fragility of starch (Zhang and Hubar, 2005). It measures the ease with which starch can be disintegrated, an indication of its degree of organization. The result of this study shows that the modified starches have low stability under shear stress and heating during cooking based on the breakdown viscosity. The modified starches have least tendency to resist shear forces during processing under high temperature (Falade and Ayetigbo, 2015). Ali and Hasnain (2014) reported that breakdown viscosity gives an indication of hot paste stability and documented that the smaller the break down viscosity, the higher the paste stability.

Pasting temperature is one of the pasting properties that is of concern to the food processor. The pasting temperature is the temperature range at which the starch granular structure is ruptured (Ikegwu et al., 2010). The pasting temperature is a measure of the temperature at which starch starts to thicken. It is the minimum temperature required to cook the banana starch. Therefore, energy cost can be calculated from the pasting temperature. The pre-gelatinization and annealing processes increased the pasting temperature of the banana starch, with annealing having greater effect. The modification processes may have strengthened the intermolecular network and increased the crystallinity of the starch granules (Kapelko et al., 2013). The rearrangement of amylose and amylopectin molecules in the starch granules may have occurred during the modification processes (Onimawo and Akubor, 2012). This probably led to the increase in the stability of the molecular interaction within the starch granules (Ali and Hasnain, 2014).Thus, high energy is required to overcome the intermolecular forces that bound the molecules together in the starch granules and hence, the higher pasting temperatures of the modified banana starches. Onimawo and Akubor (2012) showed that if aqueous starch suspension is maintained for a period at temperature below the gelatinization temperature, a process described as tempering or annealing, the gelatinization temperature is increased due to the reorganization of the structure of the starch granules. Annealing was reported to cause changes to starch structure and properties (Aurorea et al., 2009). The degree of the changes was dependent on the moisture content during the annealing process and the source of the starch (Anuonye et al., 2012). The previous studies showed that the effect of physical modification of starch was due to either crystallization or recrystallization or perfection of the small crystalline regions of the starch 
granule (Ikegwu et al., 2010). Onimawo and Akubor (2012) reported that the extents of starch chain associations within the amorphous regions and the degree of crystallinity were altered during heat moisture treatment of normal maize, waxy maize, high amylose maize, potatoes and lentil starches.

The pasting times of the starches were not significantly different $(p>0.05)$. The pasting time increased, though not significantly $(\mathrm{p}>0.05)$ from $5.84 \mathrm{~min}$ for the unmodified starch to $5.95 \mathrm{~min}$ for the pre gelatinized starch and 5.90 min for the annealed starch. The pasting time is the time in minute at which the peak viscosity occurred, indicating that the modified banana starches with lower gelatinization temperatures and similar peak time are likely to cook easier than the unmodified banana starch. Pregelatinized starches can be used without cooking. Many pre-gelatinized starches are used in dry mixes such as instant pudding mixes where they disperse readily with high -shear stirring or when with sugar or other dry ingredients (Moorthy,

2002).

Table 3: Pasting properties of unmodified and modified starches from unripe banana fruit

\begin{tabular}{|l|l|l|l|}
\hline Parameters & Unmodified starch & Pre-gelatinized starch & Annealed starch \\
\hline P V(RVU) & $159.57 \pm 0.07^{\mathrm{c}}$ & $171.47 \pm 0.02^{\mathrm{b}}$ & $178.53 \pm 0.02^{\mathrm{a}}$ \\
\hline $\begin{array}{l}\text { Final visco } \\
\text { viscosity(RVU) }\end{array}$ & $237.57 \pm 0.08^{\mathrm{c}}$ & $238.7 \pm 0.09^{\mathrm{b}}$ & $245.14 \pm 0.02^{\mathrm{a}}$ \\
\hline $\begin{array}{l}\text { Setback viscos } \\
\text { viscosity(RVU) }\end{array}$ & $217.41 \pm 0.02^{\mathrm{c}}$ & $215.94 \pm 0.07^{\mathrm{a}}$ & $220.5 \pm 0.03^{\mathrm{a}}$ \\
\hline $\begin{array}{l}\text { Breakdown viscos } \\
\text { viscosity (RVU) }\end{array}$ & $20.16 \pm 0.02^{\mathrm{c}}$ & $22.76 \pm 03^{\mathrm{b}}$ & $24.62 \pm 0.02^{\mathrm{a}}$ \\
\hline Pasting time(min) & $5.84 \pm 0.05^{\mathrm{a}}$ & $5.95 \pm 0.02^{\mathrm{a}}$ & $5.90 \pm 0.01^{\mathrm{a}}$ \\
\hline Pasting temperature $\left({ }^{\circ} \mathrm{C}\right)$ & $84.80 \pm 0.06^{\mathrm{a}}$ & $85.66 \pm 0.04^{\mathrm{c}}$ & $87.15 \pm 0.03^{\mathrm{b}}$ \\
\hline
\end{tabular}

Values are means \pm standard deviation of 3 replicates. Means within a column with the same superscript were not significantly different $(\mathrm{p}>0.05)$.

\section{Conclusion}

Based on the results of this study, it is concluded that both pre gelatinization and annealing processes decreased the crude fiber, moisture and carbohydrate contents but increased the crude protein and ash contents of the banana starch, although not significantly. The pregelatinization and annealing processes decreased the water absorption capacity and foaming capacity but increased the oil absorption capacity and emulsion stability. Only the pre gelatinization process increased the emulsion stability of the banana starch. The pre gelatinization and annealing processes increased all the pasting properties of the banana starch evaluated. The pasting and functional properties lend the unmodified and modified banana starches to various food applications.

\section{Recommendation}

Based on the result of this study, it is recommended that the performance of the unmodified and modified banana starches in baked products should be evaluated. The storage stability of the banana starches should be assessed.

\section{References}

A.O.A.C. (2010). Official methods of analysis. Association of Analytical Chemists, Washington, DC.

Adegunwa, M.O, Bakare, H.A., Alamu, E.O. and Abiodun, O.K. (2012). Processing effects on chemical, functional and pasting properties of cowpea flour from different varieties. Nigerian Food Journal, 30(1): 67- 73.

Aina, O.K., Mu T., Arogundade L.A., Deng F. and Chen J. (2009). Physicochemical 
characterization of starches from some Nigerian and Chinese roots and tubers. African Journal of Food Science, 6(11): 317-329

Ali, T.M., and Hasnain, A. (2014). Morphological, Physicochemical, and Pasting Properties of Modified White Sorghum (Sorghum bicolor) Starch. International Journal of Food Properties, 17(3): 523-535.

Anuonye, J.C, Ndaliman, M, Elizaberth, O. U and Yakubu, M.C.(2012).Effect of blanching on the composition and acceptability of blends of unripe banana and pigeon pea flours. Nigerian Food Journal, 30(1): 116-123.

Aurorea, G.,Parfaitb, B., and Fahrasmaneb, L. (2009). Bananas, raw materials for making processed food products. Trends in Food Science \& Technology, 20: 7891.

Bakare, H.A., Osundahunsi, O.F. and Adeunwa, M.O. (2012). Composition and pasting properties of breadfruit (Artocarpus communis Forst) from South-West Nigeria. Nigerian Food Journal, 30(1): 11-17

Chin, S. and Bertoft, E. (1998). The molecular structures of starch components and their contribution to the architecture of starch granules: a comprehensive review. Starch/Staerke, 62(8): 389-420.

Chinma, C.E, Abu, J.O., James, S. and Iheanacho,M (2012). Chemical, functional and pasting properties of defatted starches from cowpea and soybean apploication in stiff porridge preparation. Nigerian Food Journal, 30(2): 80-88.

Falade, K. O. and Ayetigbo, O. E. (2015). Effects of annealing, acid hydrolysis and citric acid modifications on physical and functional properties of starches from four yam (spp.) cultivars- Dioscorea. Food Hydrocolloids, 43: 529-539.

Gallant, D.J., Faisant, N., Brouchet, B. and Champ, M. (1995). Banana starch breakdown in human small intestine studied by electron microscopy. European Journal of Clinical Nutrition, 49: 98-104.
Kapelko, $\quad$ M., Zięba, $\quad$ T., Gryszkin, A., Styczyńska, M. and Wilczak, A. (2013). Properties of retrograded and acetylated starch produced via starch extrusion or starch hydrolysis with pullulanase. Carbohydrate Polymers, 97(2):551-557.

Ikegwu, O.J., Odo, M.O. and Okolk, E.C. (2011). Effect of annealing on the physicochemical properties of some under utilized legume starches. Nigerian Food Journal, 29(1): 19-28

Ikegwu, O.J., Okechukwu, P.E. and Ekumankana, E.O. (2010). Physicochemical and pasting characteristics of flour and starch from achi (Brachustegia eurycoma). Journal of Food Technology, 8(2): 58-66.

Langkilde, A.M. (2002). Effects of highresistant-starch banana flour (RS2) on in vitro fermentation and small-bowel excretion of energy, nutrients, and sterols: anileostomy study. American Journal of Clinical Nutrition, 75(2): 104-111.

Mohapatra, D., Mishra, S., and Sutar, N. (2010). Banana and its by product utilization: an overview. Journal of Scientific and Industrial Research, 69: 323-329

Moorthy, S.N. (2002). Physicochemical and functional properties of tropical tuber starches: A review. Starch, 54(12): 559592

Onimawo I.A and Akubor P.I. (2012). Food chemistry (Integrated approach with biochemical background). 2nd edn. Joytal Printing Press, Agbowo, Ibadan, Nigeria

Ovando-Martinez, M.C. (2009). Unripe banana flour as an ingredient to increase the undigestible carbohydrates of pasta. Food Chemistry, 113: 121-126.

Sandhu, K.S. and Singh, N. (2007). Some properties of corn starches. II: Physicochemical, gelatinization, retrogradation, gel textural properties. Food Chemistry, 101:1409-1507.

SPSS. (2008). Statistical package for social sciences (SPSS). version SPSS 16.0.SPSS Inc., Chicago, IL, USA; 2008. 
Yasumatsu, J., Gomand, S.V., Fierens, E., and Delcour, J.A. (1972). Production, structure, physicochemical and functional properties of maize, cassava, wheat, potato and rice 815 es. Starch/Staerke, 67(1-2): 14-2,. 815

Yusuf, A.A., Ayedun, H. and Longunleko, G.B. (2007). Functional properties of unmodified and modified jackbean (Canrala ensitrmis) starches. Nigeria Food Journal, 25(2): 141-149.

Zavareze, E.D.R. and Dias, A.R.J. (2011). Impact of heat- moisture treatment and annealing in starches: A review. Carbohydrate Polymers, 83:317-328.

Zhang, J. Y. and Huber, K. C. (2005). Heatmoisture treatment under mildly acidic conditions alters potato starch physicochemical properties and digestibility. Carbohydrate Polymers, 98(2): 1245-1255.

Zhang, P., Whistler, R. L., BeMiller, J. N. and Hamaker, B. R. (2005). Banana starch: production, physicochemical properties and digestibility-a review. Carbohydrate Polymer, 59: 443-458.

$\begin{array}{ll}\text { Received } & \text { : January, 2019 } \\ \text { Revised } & \text { : March, 2019 } \\ \text { Published } & \text { : June, 2019 }\end{array}$

